\title{
Do Harvest Practices of Bromeliads and Forest Management in Sierra Norte of Oaxaca Have a Negative Effect on their Abundance and Phorophyte Preference?
}

\author{
Yetlanezi Velázquez-Cárdenas ${ }^{1 *}$, Beatriz Rendón-Aguilar ${ }^{2}$ and \\ Adolfo Espejo-Serna ${ }^{2}$
}

\begin{abstract}
The present study recorded inhabitants' traditional knowledge and uses of bromeliads and the phorophytes present in their ecosystems in two localities of Oaxaca. We also evaluated the effect of harvest practices on the abundance and distribution of the populations of these epiphytes on different phorophytes, considering the existence, or not, of a Forest Management Program. Structured interviews were conducted with 60 adults to identify the species of bromeliads of greater cultural importance (BGCI). We identified recurrent harvest sites (RHS) and occasional harvest sites (OHS) in order to estimate the abundance and phorophyte preference of BGCI. Traditional names and uses of epiphytes and phorophytes are described; it was identified that Tillandsia deppeana, T. lucida and Catopsis occulta had the highest BGCI in both localities. Their populations showed greater abundance values in OHS in both localities compared with RHS $\left(\chi^{2} g l 6=296.99, p<0.05\right)$. T. deppeana and $T$. lucida were shown to prefer Quercus elliptica, while distribution of $C$. occulta showed a preference for Q. rugosa and Pinus oocarpa; however, phorophyte preference patterns of bromeliads may be influenced by the intensity of forest management. Decrease in abundance as the size category increased was recorded in three species, as well as the adult harvest. Finally, the inhabitants of both communities demonstrate similarities in their traditional knowledge, the intensity of harvest may be a factor influencing their abundance and preference of phorophytes, but also forest management programs determine the availability of bromeliads populations, due to the phorophytes specificity that some bromeliads exhibited.
\end{abstract}

Keywords: Catopsis; Ethnobotany; Host Preference; Tillandsia; Zapotec People.

\footnotetext{
1 Centro de Investigación de la Biodiversidad y Cambio Climático. Universidad Tecnológica Indoamerica, Machala y Sabanilla, Quito EC170301, Ecuador.

2 División de Ciencias Biológicas y de la Salud, Departamento de Biología, Universidad Autónoma Metropolitana-Iztapalapa, Ciudad de México 09340, México.

* Corresponding author $\bowtie$. E-mail address: YVC (xeniamitzi05@gmail.com), BRA (bra@xanum.uam.mx), AES (aes@xanum.uam.mx).
} 


\section{SIGNIFICANCE STATEMENT}

Bromeliads are one of the most important species used for ornamental and magic-religious purposes within local communities of Mexico. Because most of them are gathered from wild, concern on the effect of these practices on plant populations contributed to regulate them. For some decades, Mexican government has implemented forest management programs in order to provide economic income to local people through extraction forest resources and to protect them. However, the benefits of these programs on structure and composition of forests depends on how they are designed. This paper contributes to understand the cultural value of these species inside two indigenous communities of Mexico and to understand the effect of harvest practices on some ecological parameters of bromeliads populations, as well as the effect of forest management programs on bromeliads availability, based on the concept of phorophyte preference, which seems opposite to the forest species proposed in these programs.

\section{INTRODUCTION}

Through their history, human populations have interacted with other living organisms and as with environmental components, which has led to the construction of traditional knowledge of the natural world. This traditional knowledge is defined as the perceptions, beliefs, customs, forms of uses and management of natural resources and the role that play inside each culture (Ticktin et al. 2007; Lepofsky 2009; LunaJosé and Rendón-Aguilar 2012). One of the botanical families that reflect this traditional knowledge, because it has been valued for its attributes (e.g., forms, colours, size) is the Bromeliaceae family. A recent synthesis on the use of bromeliads in Latin America indicates that 78 species are used to meet different social needs such as medicine, food, ceremonial uses, ornamental uses, natural fibers or living fences (Hornung-Leoni 2011).

In Mexico, people have included the Bromeliaceae family within their cultural practices since preHispanic times, as has been reported for species of the genera Aechmea Ruiz \& Pav., Bromelia L., Catopsis Griseb., Pitcairnia L'Hér., Tillandsia L., and Vriesea Lindl. (Bennett 2000; Hornung-Leoni 2011). Currently, different species of bromeliads are used in various regions of the country, for different purposes. In Tamaulipas, people use B. balansae to make traditional drinks and sweets, while in the region of Huasteca, A. bracteata (Sw.) Griseb. and T. imperialis E. Morren ex Mez are used for medicinal purposes, and in Hidalgo, leaves juice of Hechtia podantha Mez is used to curd cheese (Villavicencio and Pérez 2006). In Oaxaca, in the southeast Mexico, the largest number of bromeliad species in the country has been recorded (Espejo-Serna et al. 2004; Espejo-Serna and López-Ferrari 2018). Like in other regions, bromeliads in Oaxaca have been linked to the traditions of diverse ethnic groups, mainly in festivities or religious events as ornamental features, as they are considered plants of great cultural beauty (Sandoval-Bucio et al. 2004; Mondragón and Villa-Guzmán 2008; Mondragón 2008; Rendón-Aguilar 2017). In addition to this important cultural relationship, bromeliads have a fundamental ecological role in terrestrial ecosystems, as they are essential organisms maintaining the relative humidity of forests as well as providing food and habitat to a wide variety of living beings (Mondragón-Chaparro and Cruz-Ruiz 2008; Mondragón and Cruz 2009; Hornung-Leoni 2011).

Despite the cultural and ecological importance of bromeliads, these plants face negative anthropic factors that severely affect survival of their populations. The high demand for bromeliads in magicalreligious festivities and for ornamental purposes at the local or regional level has provoked an intense gathering of wild individuals with flowers, which prevents them from completing their life cycle, including reproduction (Guess and Guess 2002; Beutelspacher and Farrera 2007; Haeckel 2008; Hernández-Cárdenas et al. 2014; Jiménez-López et al. 2019). Some species that face these risks are Tillandsia macdougallii L.B. Sm., T. violacea Baker, T. juncea (Ruiz \& Pav.) Poir., T. multicaulis Steud., and T. punctulata Schltdl. \& Cham. in Veracruz (Winkler et al. 2007; Mondragón-Chaparro and Ticktin 2011) and Catopsis berteroniana (Schult. \& Schult. f.) Mez, T. gymnobotrya Baker, T. carlos-hankii Matuda, and Viridantha plumosa (Baker) Espejo in Oaxaca (Mondragón and Villa-Guzmán 2008).

Changes in plant cover for agricultural and forestry use have also decreased the abundance and distribution of many species of this botanical family, because 225 of the 422 bromeliad species registered in Mexico are epiphytic; that is, they need to stay on trees (phorophytes) to survive (EspejoSerna et al. 2004; Espejo-Serna and Lopez-Ferrari 2018). Wolf (2005) reports that in a pine-oak forest in southern Mexico (Chiapas), deforestation is directly related to the decrease in epiphytic biomass, including bromeliads. Further, it has been reported that certain species of phorophytes exhibit morphophysiological characteristics that favor the establishment and growth of epiphytes, as Ramírez-Martínez et al. (2018) demonstrated with Tillandsia carlos-hankii, an epiphyte that is preferably established on individuals 
of Quercus rugosa Née, Q. laurina Bonpl., and $R a$ panea juergensenii $\mathrm{Mez}$ in a pine-oak forest in the state of Oaxaca.

In Oaxaca, as in other parts of Mexico, populations of different bromeliad species are subject to human pressures, like intensive deforestation. This state has the third-highest deforestation rate in Mexico, with cuttings exceeding 24 thousand ha for year (Velázquez et al. 2003), which causes a significant loss of trees that epiphytic bromeliads and other organisms need to survive. Of equal importance are the gathering practices of reproductive individuals, which are used in traditional festivities (Mondragón 2008; Solano et al. 2010; Rangel-Landa et al. 2016).

In this context, the present study seeks to understand the following questions: What is the traditional knowledge that the inhabitants of two localities of the Sierra Norte de Oaxaca have on the species of bromeliads and the phorophytes that exist in their ecosystems? Does the intensity of harvest influence the distribution of bromeliads on the phorophytes? Do harvest practices affect abundance and distribution of the populations of these epiphytes? Do forest management practices affect bromeliad and phorophytes populations? This research showed the negative effect of harvest practices on abundance and phorophyte preference of bromeliads, as well as the potential importance to incorporate traditional knowledge and scientific results in the development of regulations for forest management and conservation programs.

\section{MATERIAL AND METHODS}

\section{Study area}

The study was carried out in two localities of the mountainous system of the Sierra Norte de Oaxaca: San Juan Tabaá (SJT), which is located at coordinates $17^{\circ} 17^{\prime}-17^{\circ} 21^{\prime} \mathrm{N}$ and $96^{\circ} 11^{\prime}-96^{\circ} 15^{\prime} \mathrm{W}$, between 500 and $2,100 \mathrm{~m}$ a.s.l. elevation, and occupies an area of 2,769 ha (Figure 1). Santo Domingo Yojovi (SDY), which belongs to the municipality of San Andrés Solaga, is located at coordinates $17^{\circ} 17^{\prime}$ $-17^{\circ} 18^{\prime} \mathrm{N}$ and $96^{\circ} 12^{\prime}-96^{\circ} 13^{\prime} \mathrm{W}$, between 500 and 2,400 $\mathrm{m}$ a.s.l., covering an area of 1,205 ha (Castellanos et al. 2005). Both areas are characterized by pine-oak, oak, and mountain cloud forests (INEGI 2011) (Figure 1).

The inhabitants of this region are indigenous people belonging to the Zapotec culture, speaking both Zapotec and Spanish, and have inhabited the area since before the arrival of Spanish people in 1521 (Castellanos et al. 2005; Bautista 2017). Therefore, we would expect within these communities an extensive and deep knowledge of their local environment and, in particular, bromeliads, despite the current changes in the use of their natural resources due to forest management programs implemented in recent decades (CONAFOR 2014) that have impacted their perception and management of forests.

SJT has had a timber Forest Management Program authorized by the National Forestry Commission since 2010 (CONAFOR 2014). With this program, people in the community are prohibited from harvesting wild plants, such as bromeliads, and are only allowed to collect firewood-which is still the main source of fuel in homes - at authorized sites. However, as detailed below, we identified recurrent harvest in the proximity of urban area in both. In contrast, SDY, at the time of this study, lacked of a Forest Management Program, so the municipal authority allows people to harvest bromeliads, firewood and other resources; wood harvesting is carried out in authorized areas within the community.

\section{Data collection and analysis}

In July 2015, an exploratory field trip was conducted to present the project to the local authorities, in order to corroborate previous information about the existence of harvest practices of bromeliads in these communities (Rendón-Aguilar 2017) and to obtain formal permission to carry out the research. From this exploration we were informed of the dynamics of the use of bromeliads, the existence of different bromeliads with variation in their phenology and the differences of forest management strategies between the two communities. Later field trips were then undertaken quarterly, from September 2015 to April 2017. Voucher specimens of different useful bromeliads were obtained in triplicate. In the case of epiphytes, their phorophytes was collected, also in triplicate. Specimens were processed according to the methods proposed by Aguirre (1986) and Wendt (1986), and deposited in the herbaria UAMIZ (Thiers [continuously updated]). They were taxonomically determined by experts of each family.

\section{Traditional ecological knowledge, uses and management}

To record inhabitants' traditional ecological knowledge about the management and use of bromeliads and phorophytes, 30 interviews were conducted in each locality (Add File 1). The following questions were asked:

- What are the names and features of bromeliads and phorophytes that people recognize?

- What is the cultural importance of bromeliads for the inhabitants? 
- What are the uses and management of this species?

- Where do they get bromeliads?

- Do bromeliads have ecological functions for the inhabitants?

- How did they learn about bromeliads?

Adding to these interviews, we searched for people recognized in their communities as bromeliad connoisseurs (collaborators), through the snowball method proposed by Goodman (1961) and Bernard (2006). The identification of bromeliad connoisseurs was very important, as these individuals helped us to obtain information about the local names of bromeliads and trees, their uses and the importance of these natural resources in the local culture. In total, 60 semistructured interviews were accomplished for this investigation. Bromeliad harvest practices were documented through participative observation with local women.

\section{Bromeliads of greater cultural impor- tance (BGCI)}

The outstanding value method was used to identify BGCI and thus evaluate only bromeliad populations of those species highlighted through interviews. This method considered the order and frequency in which species were mentioned or described by the informants in a free list. Those species more mentioned, as well as those mentioned in the first places, were considered BGCI (Trotter and Logan 1986; Quinlan et al. 2002).

\section{Choice of sampling sites}

Based on interviews, we identified those places, forbidden or not, where the people gathered firewood and they took advantage to harvesting bromeliads, even in SJT, where the bromeliad harvest was restricted, so we asked about where firewood were usually harvested, as well as places where it is difficult to get them. From this information, two different sites were chosen in each location: i) recurrent harvest sites (RHS), classified as being easily accessible areas due to their proximity to rural roads (terracerías and veredas) to carry out the harvest of firewood, and ii) occasional harvest sites (OHS), areas that due to their difficulty of access are very infrequently visited, as extraction of firewood was not allowed (Figure 1). Three sampling plots were established for RHS and three plots for OHS in each of the two locations, for the evaluation of a total of 12 plots. Each plot was 60 $\mathrm{m} \times 10 \mathrm{~m}$ and was divided into six subplots of $10 \mathrm{~m} \times$ $10 \mathrm{~m}$. Of these, only the first, third and fifth subplots were sampled. We recorded the following information:

\section{Tree community}

Trees with a diameter basal area $(\mathrm{DBH})>7 \mathrm{~cm}$ or more were marked and measured with a diametric tape. To describe community structure, we calculated the following variables: i) frequency $(\mathrm{F})$, the number of individuals per species in the sampled area; ii) basal area $(\mathrm{AB})$, obtained as $=\pi(\mathrm{DBH} / 2)^{2}$, iii) volume of the canopy (VC): in the case of Pinus spp. trees, volume was calculated as a cone; volume of the rest of the tree species was calculated as a cylinder, then relative
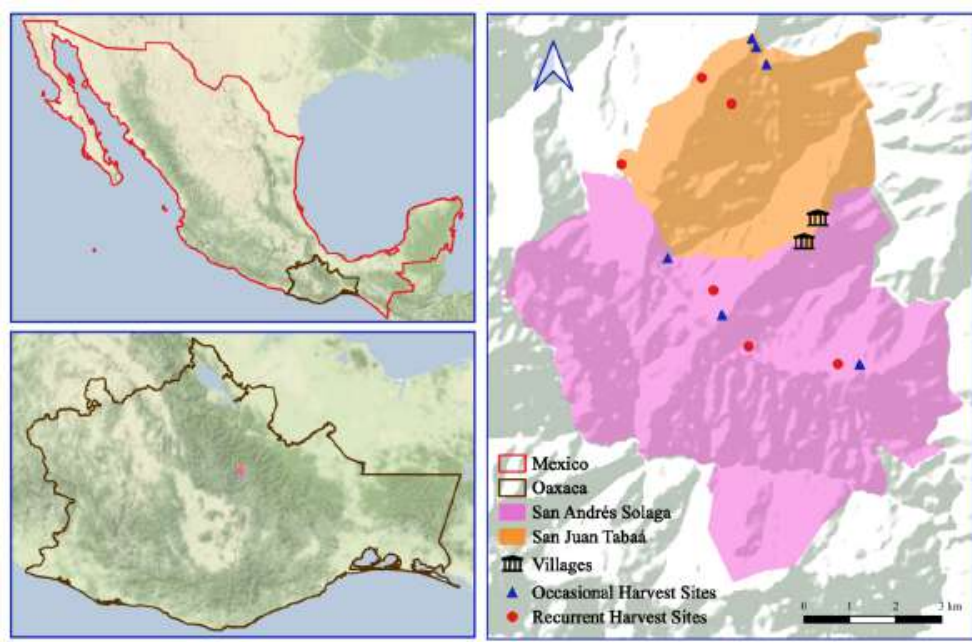

Figure 1. Study Area. Top left, Mexico; Bottom left, State of Oaxaca. Right, municipalities of San Juan Tabaá (SJT) (orange) and San Andrés Solaga (pink), in the Sierra Norte of Oaxaca. Urban areas (villages) of both localities, occasional harvest sites (OHS) and recurrent harvest sites (RHS) are indicated (Elaborated by: LA Bernal-Ramírez). 
values were obtained (Bernal et al. 2005; RamírezMartínez et al. 2018).

\section{Abundance of bromeliads}

In each tree, the number of individuals of the BGCI were counted, dividing them into approximate size categories, defined as follows: i) seedling: $<5 \mathrm{~cm}$; ii) juvenile 1: $>5 \mathrm{~cm}$ and $<15 \mathrm{~cm}$; iii) juvenile 2 : $>15 \mathrm{~cm}$ and $<25 \mathrm{~cm}$; iv) adult: $>25 \mathrm{~cm}$ or with presence of inflorescence regardless of size; and vi) with the presence of fruits and seeds. An $\chi^{2}$ test between absolute abundance and RHS and OHS respectively, in both SJT and SDY, was conducted in order to test the null hypothesis that absolute abundance is independent of forest management.

\section{Preferential occupation of phorophytes}

The total number of trees occupied by each species of BGCI was compared through a $\chi^{2}$ test in order to assess whether the distribution of bromeliads on different species of phorophytes was simply due to the availability of tree individuals, independent of the species they belong to (which would correspond to the distribution expected by chance), or if said distribution differed from what would be expected by chance, in which case it could be concluded that there would be preferences for some species of phorophytes over others, or that some phorophytes would be limiting (Bernal et al. 2005; Ramírez-Martínez et al. 2018). Subsequently, a Haberman residue analysis (1973) was carried out to identify which species of phorophytes were preferred or avoided, by the bromeliads studied. Furthermore, to avoid a statistical error type I, a Bonferroni correction was performed, adjusting the threshold value of $\mathrm{p}$ to 0.0125 (Ramírez-Martínez et al. 2018). To evaluate these results, data from the three repetitions of each site (RHS and OHS) were joined.

\section{RESULTS AND DISCUSSION}

\section{Traditional ecological knowledge, uses and management}

In SJT, 12 species of bromeliads were recorded, of which eight were used and named in Zapotec by the inhabitants. We categorized uses of bromeliads and phorophytes according to people's answers. Uses correspond to ceremonial, ornamental and commercial (Tables 1 and 2). Ten species of phorophytes belonging to five different botanical families were identified. The inhabitants recognized eight tree species with Zapotec nomenclature; seven species had at least one local use, and only Clethra occidentalis (L.) Kuntze had no use (Table 1).

SDY showed higher richness of bromeliads and their respective phorophytes, with 14 and 11 species, respectively. Racinaea adscendens (L.B. Sm.) M.A. Spencer \& L.B. Sm. and R. ghiesbreghtii (Baker) M.A. Spencer \& L.B. Sm. did not have any use, but they were clearly recognized by inhabitants, who named both species with the same Zapotec name (shabna ghaá) (Table 1).

In SDY, 14 inhabitants were recognized as connoisseurs of bromeliads, while in SJT, collaborators identified nine. Traditional ecological knowledge that people have has been acquired through their parents and grandparents, although in both communities some collaborators mentioned that the same local experts have enriched their knowledge about the names or habitats of bromeliads. In both communities, visual or tactile recognition is used to distinguish bromeliads and phorophytes (Tables 1 and 2), as in the case of Tillandsia lucida E. Morren ex Baker, whose name in Zapotec refers to the texture of the inflorescence, or Catopsis occulta Mart.-Correa, Espejo \& López-Ferr., whose name describes the color of its inflorescence (Table 1).

With respect to phorophytes, it was observed that despite the spatial proximity between one locality and another, the pronunciation and sometimes the interpretation of a single species may differ. Such is the case of Quercus elliptica Née, whose name in SJT is interpreted as a white oak (chiche), while in SDY it is perceived as a tree whose bark is similar to the color of ash (shoyeché) (Table 2). Collaborators also recognize that bromeliads play an important role in ecosystem functions, such as collection and maintenance of water supply in forests, "housing" other organisms and providing beauty to their forests.

In both localities, bromeliads are used for ceremonial, ornamental and commercial purposes (Table 1 ); while the trees can be used preferably for fuel, as in the case of Quercus obtusata Bonpl. and Pinus chiapensis (Martínez) Andresen, others are used for construction and as tools for agriculture, such as $Q$. rugosa Née, $Q$. scytophylla Liebm., and $P$. oocarpa Schiede ex Schltdl., and still others give shade to coffee plantations, such as Agarista mexicana (Hemsl.) Judd (Table 2). In particular, in SJT, where harvest of bromeliads is restricted, it was observed that in two consecutive years, during the Holy Week celebration (religious holiday of Mexico), the inhabitants harvested bromeliads in order to decorate five floral arcs with Tillandsia lucida, T. deppeana Steud. and T. prodigiosa (Lem.) Baker (Figure 2a). Unfortunately, it was not possible to go with them to document this process. On the other hand, in SDY, it was possible to participate with women in the harvest of bromeliads (Figure $2 \mathrm{~b}$ ) in different moments. 
Table 1. Names and Uses of Bromeliads recorded in San Juan Tabaá (SJT) and Santo Domingo Yojovi (SDY).

\begin{tabular}{|c|c|c|c|c|}
\hline \multirow[t]{2}{*}{ REF. NO } & BROMELIAD SPECIES & \multicolumn{2}{|c|}{$\begin{array}{c}\text { ZAPOTEC NAME } \\
\text { (MEANING IN SPANISH) }\end{array}$} & \multirow[t]{2}{*}{ USES } \\
\hline & $\begin{array}{c}\text { Bromeliad } \\
\text { Family Bromeliaceae }\end{array}$ & $\begin{array}{l}\text { SJT } \\
\text { Shabna }\end{array}$ & $\begin{array}{c}\text { SDY } \\
\mathrm{Na}\end{array}$ & \\
\hline 11,16 & Catopsis occulta Mart.-Correa, Espejo and López-Ferr. & \multicolumn{2}{|c|}{ gaché(yellow) } & $\begin{array}{l}\text { Ceremonial, } \\
\text { Ornamental, } \\
\text { Commercial }\end{array}$ \\
\hline 29,83 & Catopsis nutans (Sw.) Griseb. & \multicolumn{2}{|c|}{ unnamed } & \\
\hline 36,4 & Catopsis paniculata E. Morren & \multicolumn{2}{|c|}{ unnamed } & \\
\hline 45,64 & Catopsis subulata L.B. Sm. & \multicolumn{2}{|c|}{$\begin{array}{l}\text { xhua } \\
\text { (similar to corn kernels) }\end{array}$} & $\begin{array}{l}\text { Ceremonial, } \\
\text { Ornamental, } \\
\text { Commercial }\end{array}$ \\
\hline $\begin{array}{l}75 \\
28\end{array}$ & $\begin{array}{l}\text { Racinaea adscendens (L.B. Sm.) M.A. Spencer and L.B. Sm. } \\
\text { Racinaea ghiesbreghtii (Baker) M.A. Spencer and L.B. Sm. }\end{array}$ & \multicolumn{2}{|l|}{ Not found } & \\
\hline 17,44 & Tillandsia deppeana Steud. & \multicolumn{2}{|c|}{$\begin{array}{l}\text { xhiga rahaza } \\
\text { (flowers growing from the same place) }\end{array}$} & $\begin{array}{l}\text { Ceremonial, } \\
\text { Ornamental, } \\
\text { Commercial }\end{array}$ \\
\hline 46,50 & Tillandsia gymnobotrya Baker & \multicolumn{2}{|c|}{$\begin{array}{c}\text { zacuan } \\
\text { (similar to bean flower, recognized as quarantine) }\end{array}$} & $\begin{array}{l}\text { Ceremonial, } \\
\text { Ornamental, } \\
\text { Commercial }\end{array}$ \\
\hline 60,77 & Tillandsia kirchhoffiana Wittm. & \multicolumn{2}{|c|}{ unnamed } & \\
\hline 62,65 & Tillandsia lucida E. Morren ex Baker & \multicolumn{2}{|c|}{$\begin{array}{c}\text { zaá } \\
\text { (grease like texture) }\end{array}$} & $\begin{array}{l}\text { Ceremonial, } \\
\text { Ornamental, } \\
\text { Commercial }\end{array}$ \\
\hline 9,32 & Tillandsia multicaulis Steud. & $\begin{array}{c}\text { rhabio } \\
\text { (small flowers distributed } \\
\text { in a circular structure) }\end{array}$ & $\begin{array}{c}\text { yeta } \\
\text { (fowers distributed in a } \\
\text { similar form like tortilla) }\end{array}$ & $\begin{array}{l}\text { Ceremonial, } \\
\text { Ornamental, } \\
\text { Commercial }\end{array}$ \\
\hline 51,61 & Tillandsia prodigiosa (Lem.) Baker & $\begin{array}{c}\text { soshchjarha/deé } \\
\text { (flower growing down } \\
\text { /leaves color similar to hash) }\end{array}$ & $\begin{array}{c}\text { yesha } \\
\text { (from similar to cob) }\end{array}$ & $\begin{array}{l}\text { Ceremonial, } \\
\text { Ornamental, } \\
\text { Commercial }\end{array}$ \\
\hline 12,23 & Tillandsia punctulata Schltdl. and Cham. & $\begin{array}{l}\text { shichaxhio } \\
\text { (duster like leaves) }\end{array}$ & $\begin{array}{c}\text { yeche } \\
\text { (spines like leaves) }\end{array}$ & $\begin{array}{l}\text { Ceremonial, } \\
\text { Ornamental, } \\
\text { Commercial }\end{array}$ \\
\hline 3,37 & Werauhia werckleana Mez & unnam & & \\
\hline
\end{tabular}

Legend: Zapotec names are indicated first and in parenthesis are the meaning in Spanish. 
Table 2. Names and uses of tree species (phorophytes) recorded in San Juan Tabaá (SJT) and Santo Domingo Yojovi (SDY).

\begin{tabular}{|c|c|c|c|c|}
\hline \multirow[t]{3}{*}{ REF. NO } & \multirow[t]{2}{*}{$\begin{array}{l}\text { Tree species } \\
\text { (phorophytes) }\end{array}$} & \multicolumn{2}{|c|}{$\begin{array}{c}\text { ZAPOTEC NAME } \\
\text { (MEANING IN SPANISH) }\end{array}$} & \multirow[t]{2}{*}{ USES } \\
\hline & & 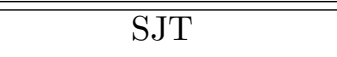 & SDY & \\
\hline & $\begin{array}{l}\text { Tree species } \\
\text { (phorophytes) }\end{array}$ & Shaga & Yaga & \\
\hline & Family Clethraceae & & & \\
\hline 14,71 & Clethra occidentalis (L.) Kuntze & \multicolumn{2}{|c|}{$\begin{array}{c}\text { becoxhozé } \\
\text { (shell like trunk) }\end{array}$} & \\
\hline & \multicolumn{3}{|l|}{ Family Ericaceae } & \\
\hline 49,70 & Agarista mexicana (Hemsl.) Judd. & $\begin{array}{l}\text { feela } \\
\text { (eagle stick) }\end{array}$ & $\begin{array}{l}\text { begha } \\
\text { (eagle stick) }\end{array}$ & $\begin{array}{l}\text { Coffee shadow, } \\
\text { fuel, } \\
\text { construction }\end{array}$ \\
\hline 5,52 & Gaultheria erecta Vent. & \multicolumn{2}{|c|}{ unnamed } & \\
\hline \multirow[t]{2}{*}{1,20} & Vaccinium aff. leucanthum Schltdl. & \multicolumn{2}{|c|}{ unnamed } & \\
\hline & Family Fagaceae & \multicolumn{2}{|c|}{ benio(oak) } & \\
\hline 31,43 & Quercus elliptica Née & $\begin{array}{l}\text { chiche } \\
\text { (white) }\end{array}$ & $\begin{array}{c}\text { shoyeché } \\
\text { (ash colored bark) }\end{array}$ & $\begin{array}{l}\text { Fuel, } \\
\text { plowing tool }\end{array}$ \\
\hline 8,33 & Quercus obtusata Bonpl. & $\begin{array}{l}\text { xnha } \\
\text { (red bark) }\end{array}$ & unnamed & $\begin{array}{l}\text { Fuel, } \\
\text { construction, } \\
\text { natural dye, } \\
\text { plowing tool }\end{array}$ \\
\hline 53,72 & Quercus rugosa Née & $\begin{array}{c}\text { xhogaveo } \\
\text { (turdy wood) }\end{array}$ & $\begin{array}{c}\text { sogaveo } \\
\text { (strong woof) }\end{array}$ & $\begin{array}{l}\text { Fuel, } \\
\text { construction }\end{array}$ \\
\hline \multirow[t]{2}{*}{7,47} & Quercus scytophylla Liebm. & $\begin{array}{l}\text { shaxho } \\
\text { (earth colored bark) }\end{array}$ & $\begin{array}{c}\text { yayo } \\
\text { (earth colored bark) }\end{array}$ & $\begin{array}{l}\text { Fuel, } \\
\text { construction }\end{array}$ \\
\hline & Family Phyllonomaceae & & & \\
\hline 39,63 & Phyllonoma laticuspis (Turcz.) Engl. & $\begin{array}{l}\text { shechhe } \\
\text { (yellow) }\end{array}$ & $\begin{array}{c}\text { yeche } \\
\text { (yellow) }\end{array}$ & Fuel \\
\hline & Family Pinaceae & $\begin{array}{l}\text { shashexhe } \\
\text { (ocote) }\end{array}$ & $\begin{array}{l}\text { shexhe } \\
\text { (ocote) }\end{array}$ & \\
\hline 4,54 & Pinus chiapensis (Martínez) Andresen & $\begin{array}{c}\text { zaa } \\
\text { (grease like texture) }\end{array}$ & & $\begin{array}{l}\text { Fuel, } \\
\text { construction }\end{array}$ \\
\hline 22 & Pinus oocarpa Schiede ex Schltdl. & Not found & $\begin{array}{l}\text { zigxhag } \\
\text { (short) }\end{array}$ & $\begin{array}{l}\text { Fuel, } \\
\text { construction }\end{array}$ \\
\hline
\end{tabular}

Legend: Zapotec names are indicated first and in parenthesis are the meaning in Spanish. 


\section{Identification of Bromeliads of greater cultural importance (BGCI)}

According to the outstanding value method, Catopsis occulta, Tillandsia deppeana and T. lucida had the highest BGCI for the inhabitants of both locations, and they were always mentioned first (Table 3).

\section{Choice of sampling sites}

According to SJT collaborators, the OHS were 3.5 $\mathrm{km}$ from downtown, while RHS were $3.8 \mathrm{~km}$, on average. In the case of SDY, OHS were $2.87 \mathrm{~km}$ away from the downtown, while the RHS were $2.64 \mathrm{~km}$ away from the trails. Even though the RHS were apparently further away in both localities, there is more accessibility due to the presence of roads (terracerías and veredas). Temperate forests (pine, oak and oakpine, Add File 2) were the main types of vegetation in the sampling sites.

\section{Tree community}

OHS: In SJT, OHS showed a tree density of 62 individuals/ha, belonging to five families, six genera and nine species; the most abundant were Quercus elliptica and Q. obtusata. Q. elliptica and Q. rugosa exhibited the greatest relative basal area, while $Q$. elliptica and $Q$. scytophylla accounted for the highest relative volume of the canopy (Add File 3). SDY, in contrast, had 80 tree individuals/ha in OHS, belonging to four families, four genera, and six species. Q. elliptica was the most abundant species, with the greatest basal area and the highest relative volume of the canopy (Add File 3).

RHS: In SJT, RHS had a lower tree density, with 44 individuals/ha, belonging to three families, four genera, and five species, with Pinus chiapensis and Quercus obtusata being the most abundant. Furthermore, these species presented the largest basal areas and canopy volumes (Add File 3). In SDY, RHS had the lowest tree density, with only 20 individuals/ha, belonging to two botanical families, two genera, and three species: Clethra occidentalis, P. chiapensis and P. oоcarpa, Pinus exhibited the highest values of basal area and volume of canopy (Add File 3).

\section{Abundance of bromeliads}

OHS: In both localities, Tillandsia deppeana, $T$. lucida and Catopsis occulta registered great abundance in the smallest size categories (Seedling, Juvenile 1 and Juvenile 2). However, in the larger size categories (Adult, Fruit/Seed), abundance of these species decreased (Figure 3a, 3b).

RHS: In SJT, abundance of the mentioned bromeliads decrease compared to that recorded for
OHS (Figure 3c, 3d). However, individuals of different size categories, from seedlings to individuals with presence of fruits and seeds, were recorded. In SDY, RHS had the lowest abundance of all the sites. Additionally, only adult individuals were recorded for Tillandsia deppeana (Figure $3 \mathrm{~d}$ ). The $\chi^{2}$ test showed significant differences $\left(\chi^{2}\right.$ gl6 $\left.=296.99, p<0.05\right)$ between OHS and RHS in SJT and SDY.

\section{Preferential occupation of phorophytes}

OHS: Bromeliads exhibited a significant preference for some phorophytes in OHS of SJT $\left(\chi^{2}\right.$ Tillandsia deppeana $=197.33 ; \chi^{2}$ T. lucida $=167.1 ; \chi^{2}$ Catopsis occulta $=483.2 ; \mathrm{gl}=5, p<0.0001)$ and $\operatorname{SDY}\left(\chi^{2}\right.$ T. deppeana $=113.75 ; \chi^{2}$ T. lucida 60.13 ; $\chi^{2}$ C. occulta $\left.=235.11 ; \mathrm{gl}=4, p<0.0001\right)$, regardless of their frequency. For example, in SJT, the tree species with high frequency were Quercus rugosa and Q. obtusata. However, they were limiting phorophytes for $T$. deppeana, which exhibited preference for $Q$. elliptica and Q. scytophylla. T. lucida showed preference for $Q$. elliptica and Q. obtusata, $Q$. rugosa and Phyllonoma laticuspis were limiting. C. occulta preferred $Q$. rugosa for its establishment, while $Q$. elliptica and Q. obtusata were limiting phorophytes for this bromeliad (Table 4).

In SDY, BGCI were found in 80 individual tree hosts as well as in the floor, but again, they exhibited phorophyte preferences. Tillandisa deppeana preferred Quercus elliptica, while Q. scytophylla and $P i$ nus oocarpa were limiting phorophytes. T. lucida occupied five of the six phorophyte species recorded in OHS, but showed preference only for Q. scytophylla and $P$. oocarpa was a limiting phorophyte. C. occulta preferred $P$. chiapensis and $P$. oocarpa, even when these species represent only $10 \%$ of the total trees at OHS (Table 4).

RHS: In SJT, BGCI exhibited a significant preference for some phorophytes $\left(\chi^{2} T\right.$. deppeana $=31.19$; $\chi^{2}$ T. lucida $=27 ; \chi^{2}$ C. occulta $=46.72 ; \mathrm{gl}=4$, $p<0.0001)$. The statistical analysis showed that $T$. deppeana prefer Q. obtusata and Q. rugosa. T. lucida had preference for Q. elliptica and Q. rugosa, while $C$. occulta prefer $Q$. obtusata and $Q$. rugosa.

In SDY, T. deppeana exhibited a significant preference for $P$. chiapensis $\left(\chi^{2} T\right.$. deppeana $=18.56 ; \mathrm{gl}=1$, $p<0.0001$ ), while $P$. oocarpa was a limiting phorophyte (Table 4). C. occulta, and T. lucida showed a random distribution in the trees that were available at that site $\left(\chi^{2}\right.$ T. lucida $=1.05 ; \chi^{2}$ C. occulta $=3.24$; $\mathrm{gl}=1, p<0.0001)$, it means, that the distribution of bromeliads on phorophytes was simply due to the availability of tree individuals. 


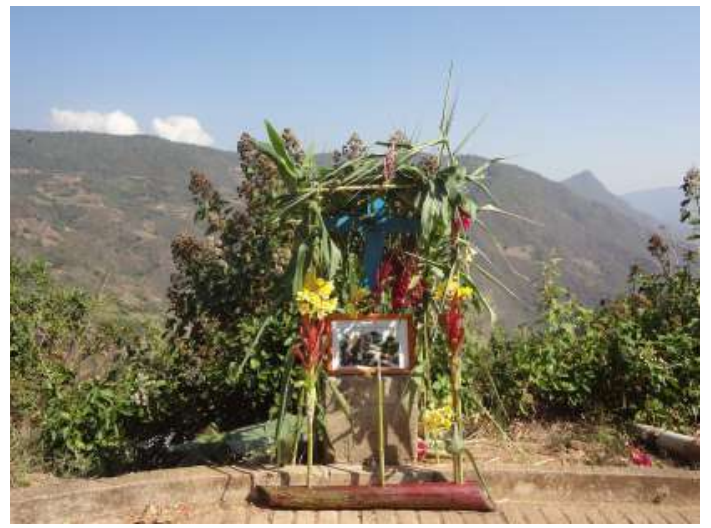

$\mathrm{A}$

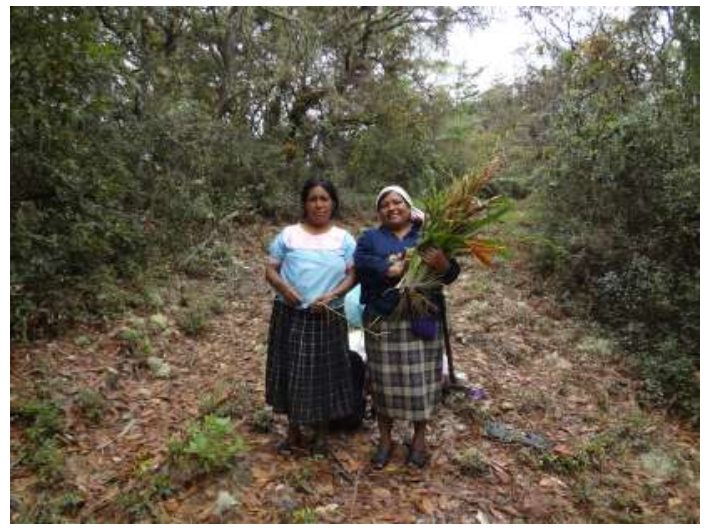

$\mathrm{B}$

Figure 2. A) Ornamental arc elaborated with flowers of T. lucida, T. deppeana y T. prodigiosa in SJT. B) Participative observation with women of SDY gathering bromeliads.

Table 3. Values of frequency (f) and order of mention (o) of bromeliads by the inhabitants of SJT and SDY

\begin{tabular}{lcccc}
\hline \hline \multirow{2}{*}{ Species } & \multicolumn{2}{c}{ SJT } & \multicolumn{2}{c}{ SDY } \\
\cline { 2 - 5 } & f & o & f & o \\
\hline \hline Tillandsia lucida & 26 & 0.68 & 25 & 0.61 \\
Catopsis occulta & 24 & 0.54 & 27 & 0.68 \\
T. deppeana & 15 & 0.36 & 20 & 0.43 \\
T. multicaulis & 7 & 0.11 & 4 & 0.11 \\
T. punctulata & 3 & 0.05 & 10 & 0.13 \\
T. gymnobotrya & 3 & 0.05 & 6 & 0.10 \\
T. prodigiosa & 1 & 0.01 & 8 & 0.11 \\
C. subulata & 0 & - & 3 & 0.05 \\
T. butzii & 0 & - & 2 & 0.03 \\
Racinaea sp. & 0 & - & 2 & 0.03 \\
\hline \hline
\end{tabular}

Legend: The bromeliads with the highest values are indicated in bold.

\section{DISCUSSION}

The cultural and economic importance of bromeliads in different communities of Oaxaca is notorious, as they are employed to magical-religious ceremonies, as an ornament in orchards, and even have non-material uses, like the perception of the "beauty of forest" (Mondragón et al. 2016; Riveros-Cañas et al. 2016; Rendón-Aguilar 2017). This is reflected in several works that have recorded this traditional ecological knowledge acquired over time by different societies as a result of continuous interaction with bromeliads (Mondragón and Villa-Guzmán 2008; Luna-José and Rendón-Aguilar 2012).

According to Castellanos et al. (2005) and Bautista (2017), SJT and SDY are Zapotec communities that share a traditional environmental knowledge; in this research we saw it in the same uses and a similar management of bromeliads and trees, although there are some nomenclatural variants in the tradi- tional classification of bromeliads. Basic morphological attributes are the main components of traditional ecological knowledge of these species, as has been reported for other ethnoclassifications (Newmaster et al. 2006). However, in the present study, inflorescence texture was registered as another trait used to distinguish Tillandsia deppeana.

Collaborators of both communities mentioned that bromeliads are beneficial for forests, since they help to collect and store rainwater, as well as housing and providing food to different animals. This view contrasts with that reported in some communities in Veracruz, where bromeliads are perceived as parasites in the ecosystems they inhabit (Toledo-Aceves et al. 2014a,b).

During the present research, we noted that in both communities, people show preference for some bromeliads. Species of Tillandsia recorded the greatest number of useful species, as occurs in other localities of Oaxaca, and also in other states of Mex- 


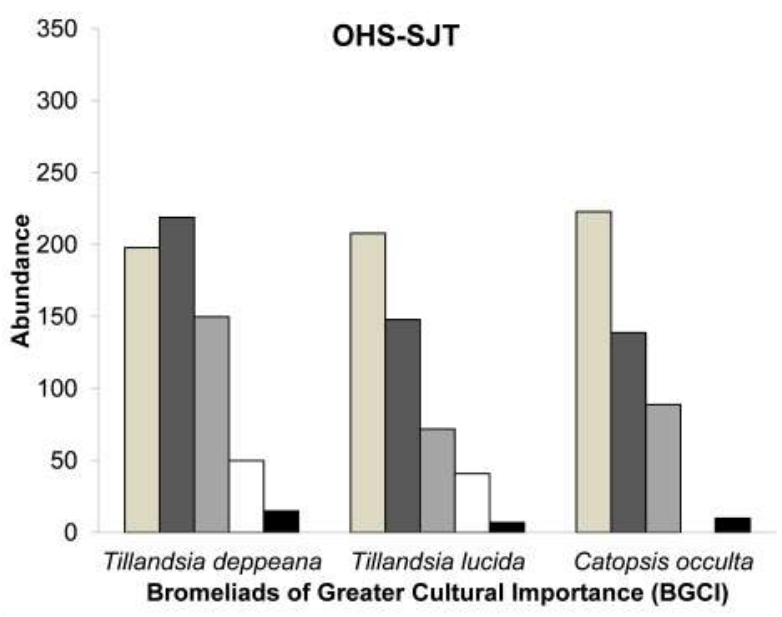

A

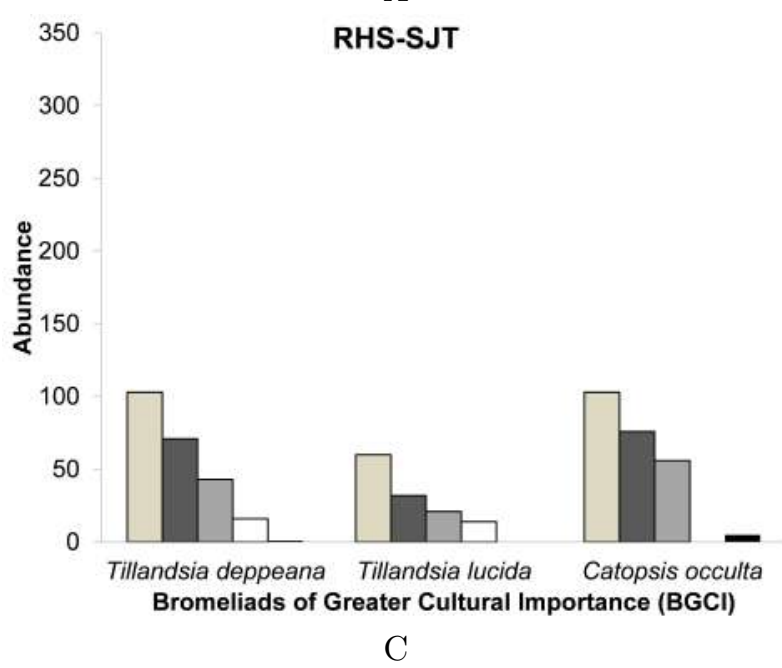

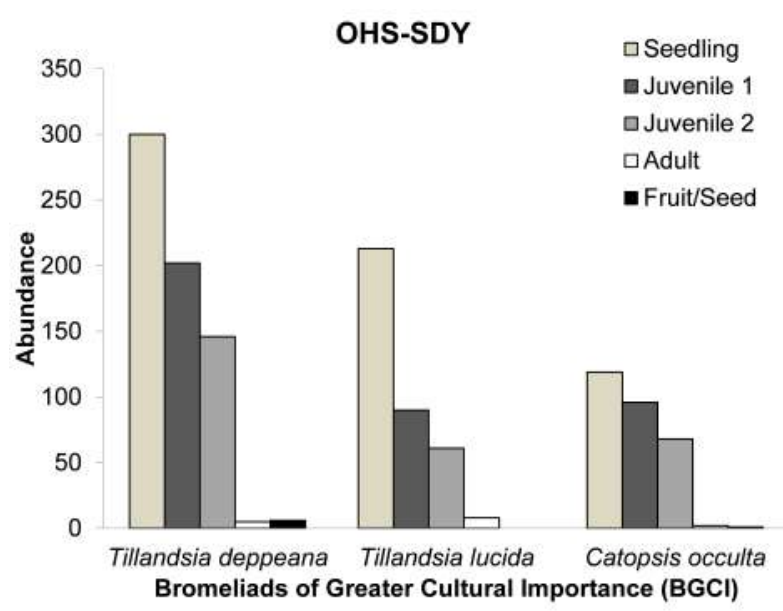

B

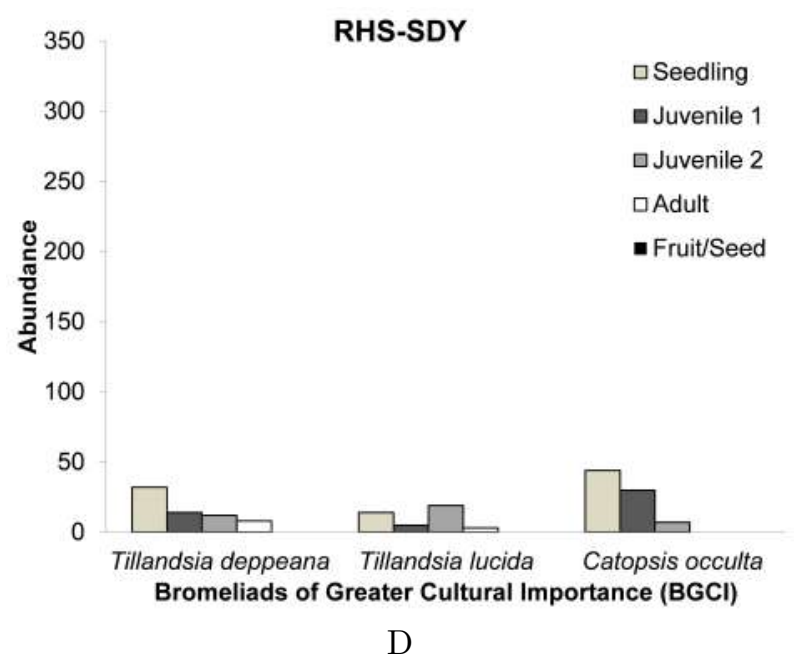

Figure 3. Abundance of seedling, juvenile 1, juvenile 2, adult and fruit/seed categories of Tillandsia deppeana, T. lucida and Catopsis occulta in A) Occasional Harvest Sites in San Juan Tabaá (OHS-SJT); B) Occasional Harvest Sites in Santo Domingo Yojovi (OHS-SDY); C) Recurrent Harvest Sites in San Juan Tabaá (RHS-SJT) and D) Recurrent Harvest Sites in Santo Domingo Yojovi (RHS-SDY).

ico (Bennett 2000; Wolf and Konings 2001; SandovalBucio et al. 2004; Beutelspcaher and Farrera 2007; Flores-Palacios and Valencia-Díaz 2007; Mondragón 2008; Mondragón and Villa-Guzmán 2008; HornungLeoni 2011; Jiménez-López et al. 2019). It should be noted that local merchants of each community are important actors in the transmission of knowledge about bromeliads, since $30 \%$ of the collaborators said that merchants teach them about traditions, names, phenology as well as ecological aspects of the plants (e.g., preference of phorophytes).

\section{Bromeliads of greater cultural impor- tance (BGCI)}

Catopsis occulta, Tillandsia deppeana, and T. lucida were identified as the bromeliads with the greatest cultural importance and the highest beauty values in both localities, and they were also sold with the highest prices in the local market. These factors could be related with the overlap of their flowering period with some local religious holidays, in addition to the perception of beauty that collaborators of both localities share about these species, as has been suggested in other studies (Flores-Palacios and Valencia-Díaz 2007; Haeckel 2008; Mondragón and Villa-Guzmán 2008).

\section{Abundance of bromeliads}

RHS in both localities recorded low abundance of BGCI compared to OHS, which evidenced the recurrent harvest activities of these species in those places, due to their accessibility and because they take advantage when harvest firewood; also, in these areas forest use is allowed, which in consequence causes modifica- 
Table 4. Preferential occupation of phorophytes of Tillandsia deppeana (Td), T. lucida (Tl) y Catopsis occulta (Co) in Occasional Harvest Sites (OHS) and Recurrent Harvest Sites (RHS) in San Juan Tabaá (SJT) and Santo Domingo Yojovi (SDY).

\begin{tabular}{|c|c|c|c|c|}
\hline \multirow[b]{2}{*}{ PHOROPHYTE } & \multicolumn{2}{|c|}{ SJT } & \multicolumn{2}{|c|}{ SDY } \\
\hline & OHS & RHS & OHS & RHS \\
\hline Quercus elliptica & $\begin{array}{c}* \\
\end{array}$ & $*$ & * & \\
\hline Quercus eцьрьса & $\mathrm{Td}, \underset{*}{\mathrm{Tl}}, C o$ & $\begin{array}{l}\mathrm{Tl} \\
*\end{array}$ & $\mathrm{Td}, C o$ & \\
\hline Quercus obtusata & $T d, \underset{*}{T l}, C_{o}$ & $\underset{*}{\mathrm{Td}, \mathrm{Co}}$ & & \\
\hline Quercus rugosa & $T d, T l, \mathrm{Co}$ & $\mathrm{Td}, \mathrm{Tl}, \mathrm{Co}$ & & \\
\hline Quercus scytophylla & $\underset{*}{*}{ }^{*}, C o$ & & $\stackrel{*}{*}{ }^{\mathrm{Tl}}, C_{o}$ & \\
\hline Phyllonoma laticuspis & $T d, T l, \mathrm{Co}$ & & & \\
\hline Pinus chiapensis & * & $*$ & $\begin{array}{c}* \\
\text { Co } \\
*\end{array}$ & $\begin{array}{c}* \\
\mathrm{Td} \\
*\end{array}$ \\
\hline Pinus oоcarpa & & & $T d, T l, \mathrm{Co}$ & $T d$ \\
\hline
\end{tabular}

Legend: Initial letters of bromeliads that exhibited preference for any phorophyte are indicated in normal, and in italic when phorophyte represented a limiting resource for bromeliads. Those phorophytes that had a relative frequency $>5 \%$ in each sampled site are indicated with *.

tions in environmental conditions and alters the availability of phorophytes (Barthlott et al. 2001; Wolf and Konings 2001; Wolf 2005; Toledo-Aceves et al. 2014a).

In general terms, there was greater abundance of adult and reproductive bromeliads in SJT than in SDY; in addition, it was observed that in OHS, and RHS of SDY, the number of seedling, juveniles and adult specimens was lower, which suggests that harvest practices have an important negative effect on bromeliad populations. It is likely that the absence of a Forest Management Program has negatively influenced the bromeliad populations. In the case of SJT, the Forest Management Program has influenced the maintenance of bromeliad and phorophyte populations.

\section{Preferential occupation of phorophytes}

It has been documented that some bromeliad species have preferences for certain phorophytes (Wolf and Konings 2001; Bernal et al. 2005; RamírezMartínez et al. 2018). Wagner et al. (2015) suggested that a strong specificity of host opens up the possibility of sympatric speciation and may allow species to coexist in a complementary niche. This assumption is supported by the fact that both species of Tillandsia present in OHS in SJT, prefer Quercus elliptica, and are limited to colonize Q. obtusata, $Q$. rugosa and Phyllonoma laticuspis, so they could be considered sympatric species; in contrast to Catopsis occulta, which preferred $Q$. rugosa and P. laticuspis and were limited in $Q$. elliptica and $Q$. obtusata.

Even when the specificity of the phorophyte is still unclear (Moffett 2000; Callaway et al. 2002; Bernal et al. 2005; Martínez-Meléndez et al. 2008; Wagner et al. 2015; Zotz 2016), it was evident that in both sampling sites, OHS and RHS, and in both localities, oaks were recorded as the tree species with the highest presence of BGCI, which is consistent with other papers (Castro et al. 1999; Callaway et al. 2002; Wolf 2005; Toledo-Aceves et al. 2014a), where Quercus spp. are mentioned as good host trees due to the ability of their bark to retain water and the ease of epiphytic seeds to anchor in them.

In the context of the Forest Management Plan by CONAFOR (2014) in SJT, our results are relevant because the main forest species considered in this program is Pinus chiapensis, and part of the proposed management includes total elimination of other species. Although this program could be successful in obtaining an adequate volume of wood from $P$. chiapensis, it could modify the composition and structure of these ecosystems, as well as transform the habitat for bromeliads and, in consequence, decrease their species richness (Barthlott et al. 2001; Merwin et al. 2003; Wolf 2005). 


\section{CONCLUSION}

The present study showed the negative effect of harvest practices on abundance and phorophyte preference of those bromeliads with the highest BGCI: Tillandsia deppeana, T. lucida and Catopsis occulta, in both locations were the study was developed, SJT and SDY. OHS presented a greater abundance of BGCI bromeliad species compared to RHS in both localities, regardless of the existence of a Forest Management Program (i.e., SJT). In general terms, $T$. deppeana and T. lucida prefer Quercus elliptica as phorophytes, while $C$. occulta showed preference for Q. rugosa and Pinus oocarpa. However, in places with intensive harvest practices, restrictive availability of phorophytes could be the main factor that determines bromeliads' phorophyte preferences. The existence of a Forest Management Program in SJT could explain the difference in the abundance of adult and reproductive bromeliads, but it has a negative effect on the availability of phorophytes because this program includes elimination of any species other than Pinus chiapensis. We propose a revision of this program in order to diversify forest management, ensure species richness, including epiphytes, like bromeliads. To avoid the loss of traditional knowledge of bromeliads, we propose to assign some areas inside these locations where inhabitants can obtain them, but also to promote their presence in the forest through propagation practices.

\section{FUNDING}

This work was supported by Consejo Nacional de Ciencia y Tecnología (CONACYT), Universidad Autonoma Metropolitana Iztapalapa (UAMIZ) throughout the Master's Program in Biology and a scholarship number 425428 to the main author.

\section{ACKNOWLEDGEMENT}

The authors express their total gratitude to the following people: The inhabitants of San Juan Tabaá and Santo Domingo Yojovi, especially to the Local Governments and the Zapotec translator Mr. Eleuterio Lorenzo Ruiz. Dr. Susana Valencia-Ávalos, Dr. Nancy Martínez-Correa and Jesús Ricardo de Santiago Gómez for the taxonomic determination of plants. Dr. David Bravo-Avilez for the field support and comments on this research. Luiz Alberto Bemal-Ramírez for elaborated the map of Study Area in this manuscript. UAMIZ Herbarium curator and researches for technical support.

\section{DATA AVAILABILITY}

The data used to support the findings of this study are available from the corresponding author upon reasonable request.

\section{CONFLICT OF INTEREST}

The authors have no conflicts of interest to declare.

\section{CONTRIBUTION STATEMENT}

Conceived of the presented idea: YVC, BRA, AES.

Carried out the experiment: YVC, BRA.

Carried out the data analysis: YVC, BRA, AES.

Wrote the first draft of the manuscript: YVC, BRA. Review and final write of the manuscript: BRA, AES. Supervision: BRA, AES.

\section{REFERENCES}

Aguirre LE (1986) Epífitas. In: Lot A, Chiang F (eds) Manual de herbario: administración y manejo de colecciones, técnicas de recolección y preparación de ejemplares botánicos. 1ed. Consejo Nacional de la Flora de México, Ciudad de México, Mexico, pp. 113-119.

Barthlott W, Schmit-Neuerburg V, Nieder J, Engwald S (2001) Diversity and abundance of vascular epiphytes: A comparison of secondary vegetation and primary montane rain forest in the Venezuelan Andes. Plant Ecology doi: 10.1023/A:1011483901452

Bautista CM (2017) Memoria histórica de TapaBaa. La defensa de la tierra, los espacios sagrados y los principios de la vida comunal en San Juan Tabaá. 2 ed. Colección diálogos pueblos originarios de Oaxaca. Oaxaca, México.

Bennett B (2000) Ethnobotany of Bromeliaceae. In: Benzing DH (ed) Bromeliaceae Profile of an Adaptative Radiation. Cambridge University Press, Cambridge, pp. 587-608.

Bernal R, Valverde T, Hernández-Rosas L (2005) Habitat preference of the epiphyte Tillandsia recurvata (Bromeliaceae) in a semi-desert environment in Central Mexico. Canadian Journal of Botany doi: 10.1139/b05-076

Bernard HR (2006) Research methods in anthropology: Qualitative and quantitative approaches. 4 ed. AltaMira Press, Plymouth, UK.

Beutelspacher BCR, Farrera SO (2007) Tradición 
vs. conservación: La "Topada de la Flor". Lacandonia 1:109-115.

Callaway RM, Reinhart KO, Moore GW, Moore DJ, Pennings SC (2002) Epiphyte host preferences and host traits: Mechanisms for species-specific interactions. Oecologia doi: 10.1007/s00442-002-0943-3

Castellanos MJ, Lorenzo RE, Castellanos PR (2005) Yaxhobe, la historia narrada y escrita por sus habitantes. Comité Comunitario de Cultura. Oaxaca, México.

Castro HJC, Wolf JD, García-Franco JG, GonzálezEspinosa M (1999) The influence of humidity, nutrients and light on the establishment of the epiphytic bromeliad Tillandsia guatemalensis in the highlands of Chiapas, Mexico. Revista de Biología Tropical 47:763-773.

CONAFOR (2014) Comunidades Instructoras 2014: Programa Desarrollo Forestal Comunitario. [http://www.conafor.gob.mx] Accessed 22 June 2020.

Espejo-Serna A, López-Ferrari AR (2018) La familia Bromeliaceae en México. Botanical Sciences doi: 10.17129/botsci.1918

Espejo-Serna A, López-Ferrari AR, Ramírez-Morillo I, Holst BK, Luther HE, Till W (2004) Checklist of Mexican Bromeliaceae with Notes on Species Distribution and Levels of Endemism. Selbyana $25: 33-86$.

Flores-Palacios A, Valencia-Díaz S (2007) Local illegal trade reveals unknown diversity and involves a high species richness of wild vascular epiphytes. Biological Conservation doi: 10.1016/j.biocon.2006.12.017

Goodman LA (1961) Snowball Sampling. The Annals of Mathematical Statistics doi: 10.1214 /aoms/1177705148

Guess V, Guess R (2002) Tillandsia lucida: Its use as a ritual offering. Journal Bromeliad Society 52:99-103.

Haberman SJ (1973) The Analysis of Residual in Cross-Classified Tables. Biometrics doi: $10.2307 / 2529686$

Haeckel IB (2008) The "Arco Floral": Ethnobotany of Tillandsia and Dasylirion spp. in a Mexican Religious Adornment. Economic Botany doi: 10.1007/s12231008-9009-8

Hernández-Cárdenas R, González-Rocha E, EspejoSerna A, López-Ferrari AR, Cerros-Tlatilpa R, Ehlers $\mathrm{R}$ (2014) Tillandsia religiosa, a new species from the state of Morelos, México. Phytotaxa doi: 10.11646/phytotaxa.184.1.7

Hornung-Leoni CT (2011) Avances sobre Usos Etnobotánicos de las Bromeliaceae en Latinoamérica. Boletin Latinoamericano y del Caribe de Plantas Medicinales y Aromaticas 10:297-314.

INEGI (2011) Prontuario de información geográfica municipal de los Estados Unidos Mexicanos. [https://www.inegi.org.mx/app/ areasgeograficas/?ag=20] Acessed 22 June 2020.

Jiménez-López DA, Solórzano J V, Vibrans H, Espejo-Serna A, Peralta-Carreta C (2019) Ceremonial Use of Bromeliads and Other Vascular Epiphytes in Cemeteries of Two Indigenous Communities of Las Margaritas, Chiapas, Mexico. Economic Botany doi: 10.1007/s12231-01909445-4

Lepofsky D (2009) The Past, Present, and Future of Traditional Resource and Environmental Management. Journal of Ethnobiology doi: 10.2993/0278-0771-29.2.161

Luna-José A de L, Rendón-Aguilar B (2012) Traditional knowledge among Zapotecs of Sierra Madre Del Sur, Oaxaca. Does it represent a base for plant resources management and conservation? Journal of Ethnobiology and Ethnomedicine doi: 10.1186/1746-4269-8-24

Martínez-Meléndez N, Pérez-Farrera MA, FloresPalacios A (2008) Estratificación vertical y preferencia de hospedero de las epífitas vasculares de un bosque nublado de Chiapas, México. Revista de Biologia Tropical 56:2069-2086.

Merwin MC, Rentmeester SA, Nadkarni NM (2003) The Influence of Host Tree Species Ticktin on the Distribution of Epiphytic Bromeliads in Experimental Monospecific Plantations, La Selva, Costa Rica. Biotropica doi: 10.1111/j.17447429.2003.tb00260.x

Moffett MW (2000) What's "Up"? A Critical Look at the Basic Terms of Canopy Biology. Biotropica doi: 10.1111/j.1744-7429.2000.tb00506.x

Mondragón D (2008) La comercialización navideña de bromelias epífitas en la ciudad de Oaxaca, México. Etnobiología 6:24-28.

Mondragón D, Cruz RGI (2009) Presence of Vaejovis franckei in epiphytic bromeliads in three temperate forest types. Journal of Arachnology doi: 10.1636/P08-85.1

Mondragón D, Villa-Guzmán DM (2008) Estudio etnobotánico de las bromelias epífitas en la co- 
munidad de Santa Catarina Ixtepeji, Oaxaca, México. Polibotánica 26:175-191.

Mondragón D, Méndez-García EMC, Morillo IR (2016) Prioritizing the Conservation of Epiphytic Bromeliads Using Ethnobotanical Information from a Traditional Mexican Market. Economic Botany doi: 10.1007/s12231-016-9332-4

Mondragón-Chaparro DM, Cruz-Ruiz GI (2008) Seasonal variation of the macro-arthropod community associated to Tillandsia carlos-hankii (Bromeliaceae) in an oak-pine forest in Oaxaca, Mexico. Brenesia 70:11-22.

Mondragón-Chaparro D, Ticktin T (2011) Demographic Effects of Harvesting Epiphytic Bromeliads and an Alternative Approach to Collection. Conservation Biology doi: 10.1111/j.1523-1739.2011.01691.x

Newmaster SG, Subramanyam R, Ivanoff RF, Balasubramaniam NC (2006) Mechanisms of ethnobiological classification. Ethnobotany 18:4-26.

Quinlan MB, Quinlan RJ, Nolan JM (2002) Ethnophysiology and herbal treatments of intestinal worms in Dominica, West Indies. Journal of Ethnopharmacology doi: 10.1016/S03788741(02)00002-8

Ramírez-Martínez A, Mondragón D, Valverde T, Chávez-Servia JL (2018) Spatial variation in host preference in the endangered epiphytic bromeliad Tillandsia carlos-hankii. Acta Oecologica doi: 10.1016/j.actao.2018.08.008

Rangel-Landa S, Casas A, Rivera-Lozoya E, TorresGarcía I, Vallejo-Ramos M (2016) Ixcatec ethnoecology: Plant management and biocultural heritage in Oaxaca, Mexico. Journal of ethnobiology and ethnomedicine doi: 10.1186/s13002-0160101-3

Rendón-Aguilar B (2017) Inventario etnoflorístico en regiones oaxaqueñas con gran biodiversidad. Universidad Autónoma Metropolitana. Unidad Iztapalapa. Informe final SNIB-CONABIO proyect JF102. Ciudad de México. [http: //www. conabio.gob.mx/institucion/proyectos/ resultados/InfJF102.pdf] Accessed 22 June 2020.

Riveros-Cañas RA, Rodríguez-Robayo KJ, Cesín Vargas A (2016) The role of bromeliads in rural livelihoods: An experience in Oaxaca, Mexico. Journal of Sustainable Forestry doi: 10.1080/10549811.2016.1203338

Sandoval-Bucio EN, Flores-Cruz M, Martínez-Bernal A (2004) Bromelias útiles de México. Cactáceas y Suculentas Mexicanas 49:100-115.
Solano GR, Cruz LG, Martínez FA, Lagunez RL (2010) Plantas utilizadas en la celebración de la Semana Santa en Zaachila, Oaxaca, México. Polibotánica 29:263-279.

Thiers B [continuously updated]. Index Herbariorum: A Global Directory of Public Herbaria and Associated Staff. New York Botanical Garden's Virtual Herbarium. [http://sweetgum.nybg.org/science/ih] Accessed 22 June 2020.

Ticktin T, Fraiola H, Whitehead AN (2007) Nontimber forest product harvesting in aliendominated forests: Effects of frond-harvest and rainfall on the demography of two native Hawaiian ferns. Biodiversity and Conservation doi: 10.1007/s10531-006-9030-0

Toledo-Aceves T, García-Franco JG, López-Barrera F (2014a) Bromeliad rain: An opportunity for cloud forest management. Forest Ecology and Management doi: 10.1016/j.foreco.2014.06.022

Toledo-Aceves T, Hernández-Apolinar M, Valverde T (2014b) Potential impact of harvesting on the population dynamics of two epiphytic bromeliads. Acta Oecologica doi: 10.1016/j.actao.2014.05.009

Trotter R, Logan M (1986) Informant consensus: a new approach for identifying potentially effective medicinal plants. In: Etkin N (ed) Plants Indigenous Medicine and Diet: Biobehavioural Approaches. 1 ed. Redgrave publishers, Bedford Hills, New York, U.S.A, pp. 91-112.

Villavicencio NMA, Pérez EBE (2006) Plantas útiles del estado de Hidalgo III. Universidad Autónoma del Estado de Hidalgo. Centro de Investigaciones Biológicas. Hidalgo, México. 51 pp.

Velázquez A, Durán E, Ramírez I, Mas JF, Bocco G, Ramírez G, Palacio JL (2003) Land use-cover change processes in highly biodiverse areas: The case of Oaxaca, Mexico. Global Environmental Change doi: 10.1016/S0959-3780(03)00035-9

Wagner K, Mendieta-Leiva G, Zotz G (2015) Host specificity in vascular epiphytes: A review of methodology, empirical evidence and potential mechanisms. AoB PLANTS doi: 10.1093/aobpla/plu092

Wendt T (1986) Árboles. In: Lot A, Chiang F (eds) Manual de herbario: administración y manejo de colecciones, técnicas de recolección y preparación de ejemplares botánicos. Consejo Nacional de La Flora de México, Mexico City, Mexico, pp. 133-142. 
Winkler M, Hülber K, Hietz P (2007) Population dynamics of epiphytic bromeliads: Life strategies and the role of host branches. Basic and Applied Ecology doi: 10.1016/j.baae.2006.05.003

Wolf JHD (2005) The response of epiphytes to anthropogenic disturbance of pine-oak forests in the highlands of Chiapas, Mexico. Forest Ecology and Management doi: 10.1016/j.foreco.2005.03.027

Wolf JHD, Konings CJF (2001) Toward the sustainable harvesting of epiphytic bromeliads: a pilot study from the highlands of
Chiapas, Mexico. Biological Conservation doi: 10.1016/S0006-3207(01)00053-2

Zotz G (2016) Plants on Plants? The Biology of Vascular Epiphytes. Springer International Publishing, Switzwerland. pp. 149-189 doi: 10.1007/9783-319-39237-0

Received: 06 August 2020

Accepted: 29 January 2021

Published: 08 March 2021 


\section{Additional Files}

Add File 1. Interview conducted in each locality (Spanish version)

Encuesta realizada a los pobladores

\section{Localidad: Clave: Fecha:}

1.- Datos del encuestado:

Nombre:

Edad:

Sexo:

Parentesco:

\section{IMPORTANCIA Y USOS}

1. ¿Conoce las bromelias?

2. ¿Cuáles son las bromelias que usted conoce?

\begin{tabular}{|l|l|l|l|l|l|}
\hline $\begin{array}{l}\text { Nombre } \\
\text { zapoteco }\end{array}$ & $\begin{array}{l}\text { Significado } \\
\text { Español }\end{array}$ & $\begin{array}{l}\text { Parte utilizada } \\
\text { Usos }\end{array}$ & $\begin{array}{l}\text { Nombre Forófito } \\
\text { Zapoteco }\end{array}$ & $\begin{array}{l}\text { Significado } \\
\text { Español }\end{array}$ & $\begin{array}{l}\text { Parte utlizada } \\
\text { Usos }\end{array}$ \\
\hline & & & & & \\
\hline & & & & & \\
\hline & & & & & \\
\hline & & & & & \\
\hline
\end{tabular}

¿Cuál es la más bonita?

¿Cuál es la que recolecta más? ¿Por qué?

\begin{tabular}{|l|l|l|}
\hline Nombre & ¿Dónde o a quién se la compra? & Precio \\
\hline & & \\
\hline & & \\
\hline & & \\
\hline & & \\
\hline
\end{tabular}

3. ¿Quién le enseñó a usted como se ocupan las bromelias?

\section{PERCEPCIÓN}

4. Cuando sale a buscar bromelias ¿Ha notado que algunos tipos de bromelias ya no existen o que ya no hay tantas como antes?

5. ¿Por qué cree que ya no existan algunas bromelias o haya menos?

\section{RECOLECCIÓN}

6. Cuando va a colectar bromelias, ¿Va usted sol@ o alguien 1@ acmompaña?

7. ¿Cuáles son los lugares donde pueden recolectar bromelias?

8. ¿Desde hace cuánto tiempo va a recolectar? ¿Con quién aprendió a recolectar? 
9. ¿Siempre ha recolectado las mismas bromelias o por qué ahora recolecta otras?

10. ¿Cada cuándo sale a recolectar bromelias?

11. ¿Cuánto tarda en llegar ahí y cuánto tiempo tarda en recolectar las bromelias?

12. Desde que usted empezó a recolectar ¿Invierte el mismo tiempo en llegar al sitio y recolectar las bromelias?

13. ¿Las bromelias que recolectan son de: árbol, suelo o de rocas?

14. ¿Utiliza alguna herramienta para recolectar las bromelias?

15. ¿Qué hace con las bromelias después de bajarla del árbol?

16. ¿Existen temporadas en las que se recolecten más bromelias? ¿Por qué?

17. ¿En qué árboles ha visto que crecen las bromelias?

18. ¿Utiliza la madera de los árboles para tener leña?

19. ¿Cuáles son los árboles que más utiliza para leña?

20. ¿Existe alguna organización con otras personas de su comunidad para recolectar las bromelias?

21. ¿Cree que las bromelias tienen alguna función en el bosque?

22. ¿Cree que sea necesario cuidar a las bromelias?

23. ¿Usted o su comunidad conocen alguna técnica o han tenido acciones para cuidar a las bromelias?

24. ¿Existen lugares dónde esté prohibido recolectar bromelias?

25. ¿Hay tipos de bromelias que estén prohibidas recolectarlas?

26. ¿Quién dice que está prohibido?

27. ¿Qué opina acerca de esas prohibiciones?

\section{VENTA}

28. ¿Quién va a vender las bromelias que usted recolecta?

29. ¿Dónde va a vender las bromelias?

30. ¿Por qué va a ese lugar?

31. ¿Existe algún procedimiento para que usted pueda vender las bromelias en ese lugar?

32. ¿Cuánto tiempo tarda en llegar a ese lugar?

33. ¿Utiliza algún transporte para llegar al lugar donde vende las bromelias?

34. Cuando llega a ese lugar para vender sus bromelias ¿Usted paga para poder venderlas?

\begin{tabular}{|c|c|c|}
\hline Uso de suelo & Comida & Otros \\
\hline Luz & Cuotas & \\
\hline
\end{tabular}

35. ¿Cuánto tiempo está en ese lugar para vender sus plantas?

36. ¿En qué meses vende más bromelias?

37. ¿En años anteriores usted vendía más bromelias o actualmente vende más?

38. ¿Cuántas bromelias vende en promedio en un día?

39. ¿Arregla de alguna manera a la bromelia para su venta? 
Add File 2. Characteristics of sampling sites in San Juan Tabaá (SJT) and Santo Domingo Yojovi (SDY). Selection was based on the preference of bromeliads with greater cultural importance (BGCI), as well as the frequency of harvest activities developed by local inhabitants: Recurrent Harvest Site (RHS) and Occasional Harvest Site (OHS).

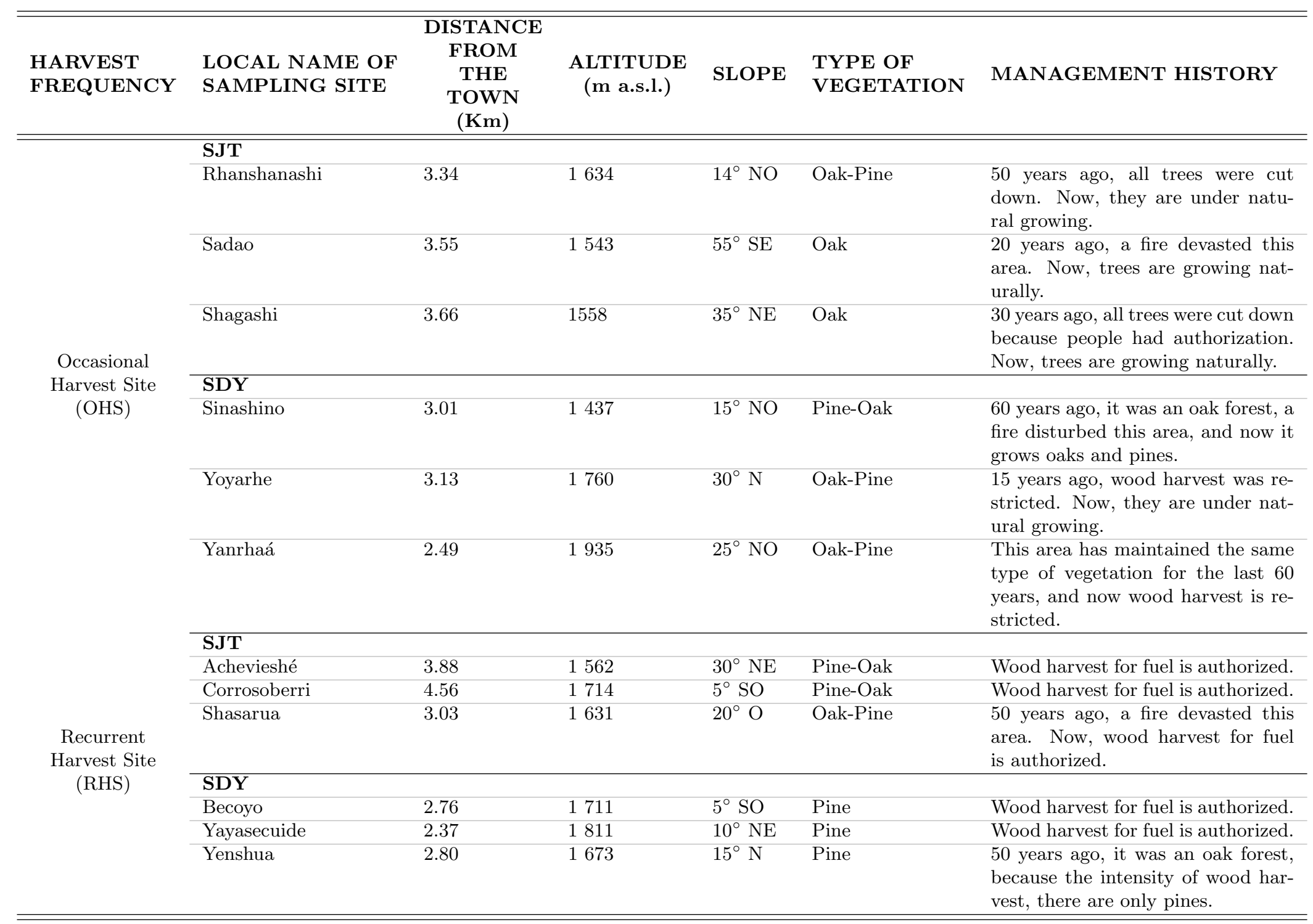


Add File 3. Tree structure in the sampling sites: Recurrent Harvest Site (RHS) and Occasional Harvest Site (OHS) in both localities: San Juan Tabaá (SJT) and Santo Domingo Yojovi (SDY). $A=$ Abundance, $R F=$ Relative Frequency, $B A=$ Basal Area; $R B A=$ Relative Basal Area; $C V=$ Canopy Volume and $R C V=$ Relative Canopy Volume

\begin{tabular}{|c|c|c|c|c|c|c|c|c|}
\hline & & TREE SPECIES & $\boldsymbol{A}$ & $\boldsymbol{R F}(\%)$ & $\overline{\boldsymbol{B} \boldsymbol{A}\left(m^{2}\right)}$ & $\boldsymbol{R B A ( \% )}$ & $\overline{C \boldsymbol{V}\left(m^{3}\right)}$ & $\overline{R C V}(\%)$ \\
\hline \multirow{14}{*}{ SJT } & \multirow{9}{*}{ OHS } & Quercus elliptica & 21 & 33.9 & 106.5 & 29.5 & 36307.9 & $\overline{62.4}$ \\
\hline & & Quercus obtusata & 13 & 21 & 71.4 & 19.8 & 6744.6 & 11.6 \\
\hline & & Quercus rugosa & 10 & 16.1 & 93.6 & 26 & 871.2 & 1.5 \\
\hline & & Quercus scytophylla & 7 & 11.3 & 35.6 & 9.9 & 10882.5 & 18.7 \\
\hline & & Phyllonoma laticuspis & 3 & 4.8 & 5.9 & 1.6 & 227.8 & 0.4 \\
\hline & & Gaultheria erecta & 3 & 4.8 & 6.8 & 1.9 & 122 & 0.2 \\
\hline & & Clethra occidentalis & 2 & 3.2 & 13 & 3.6 & 223 & 0.4 \\
\hline & & Vaccinium aff. leucanthum & 2 & 3.2 & 10.7 & 3 & 26.2 & 0.04 \\
\hline & & Pinus chiapensis & 1 & 1.6 & 17 & 4.7 & 2812.7 & 4.8 \\
\hline & \multirow{5}{*}{ RHS } & Pinus chiapensis & 15 & 35 & 151.8 & 48.9 & 103897.3 & 70.7 \\
\hline & & Quercus obtusata & 11 & 25.6 & 83.9 & 27 & 22750.7 & 15.5 \\
\hline & & Quercus elliptica & 9 & 18.6 & 34 & 11 & 9221.7 & 6.3 \\
\hline & & Clethra occidentalis & 6 & 14 & 29.6 & 9.5 & 8824.5 & 6 \\
\hline & & Quercus rugosa & 3 & 7 & 11.1 & 3.6 & 2318.9 & 1.6 \\
\hline \multirow{9}{*}{ SDY } & \multirow{6}{*}{ OHS } & Quercus elliptica & 43 & 53.8 & 132.2 & 42.8 & 91740.2 & 61.3 \\
\hline & & Quercus scytophylla & 7 & 8.8 & 110.4 & 35.7 & 49594.3 & 33.1 \\
\hline & & Pinus oocarpa & 22 & 27.5 & 42.7 & 13.8 & 4609.2 & 3.1 \\
\hline & & Agarista mexicana & 4 & 5 & 11.5 & 3.7 & 1893.9 & 1.3 \\
\hline & & Clethra occidentalis & 1 & 1.3 & 6.7 & 2.2 & 1534.4 & 1 \\
\hline & & Pinus chiapensis & 3 & 3.8 & 5.3 & 1.7 & 271.1 & 0.2 \\
\hline & \multirow{3}{*}{ RHS } & Pinus oocarpa & 13 & 65 & 87.9 & 65.9 & 21855 & 84.5 \\
\hline & & Pinus chiapensis & 6 & 30 & 44.7 & 33.5 & 3989.4 & 15.4 \\
\hline & & Clethra occidentalis & 1 & 5 & 0.8 & 0.6 & 17.7 & 0.1 \\
\hline
\end{tabular}

